\title{
Reducing the environmental footprint of church lighting: matching façade shape and lowering luminance with the EcoSky LED.
}

\author{
Christopher C. M. Kyba 1,2,*, Andrej Mohar³, Gašper Pintar ${ }^{3}$, Jurij Stare ${ }^{4}$ \\ ${ }^{1}$ GFZ German Research Centre for Geosciences, 14473 Potsdam, Germany \\ ${ }^{2}$ Leibniz Institute of Freshwater Ecology and Inland Fisheries (IGB), 12587, Germany \\ ${ }^{3}$ Euromix Ltd., 1000 Ljubljana, Slovenia \\ ${ }^{4}$ Dark-Sky Slovenia, 1000 Ljubljana, Slovenia
}

Received 27 October 2017, Accepted 20 February 2018

\begin{abstract}
In rural areas of Europe, ornamental lighting, and particularly church lighting, is often among the most important sources of light emissions from communities. In current practice of façade lighting for churches, much of the produced light misses the target area, and façade luminance is often far larger than is necessary. This results in a dramatic waste of electrical energy and significant light pollution for the surrounding areas. This article discusses the concept of sustainability with regards to cultural heritage lighting, within the context of the façade lighting of a specific church. The lighting of the Church of the Three Kings in Logatec, Slovenia was replaced in 2014. The power of the installation was reduced $96 \%$ from $1.6 \mathrm{~kW}$ to $58 \mathrm{~W}$, and spill light from the site was effectively eliminated. As a result, the church is no longer visible in nighttime satellite images of the area, indicating a reduction of waste light from the site of at least a factor of 30. This example demonstrates the dramatic extent to which more general application of lighting design principles could reduce energy consumption and light pollution in the rural European context.
\end{abstract}

Keywords: sustainable lighting, light pollution, remote sensing, church lighting, architectural lighting, VIIRS $D N B$

\section{Introduction}

As the sun sets at the end of each day, countless miniature artificial copies spring to life around the world, casting light on the domes of cathedrals, the supports of bridges, and even the faces of presidents. These lights draw attention to landmarks and cultural heritage sites, but they are not without cost. Beyond the cost of energy, these mini-suns also steal the dark from the night. They lure insects and birds to their deaths, blot out our view of the stars, and sometimes even blind us to our surroundings (Figure 1). It doesn't have to be this way. In this paper,

\footnotetext{
* Kyba CCM, Tel.: +49-331-288-28973
}

E-mail address: kyba@gfz-potsdam.de 
we use the example of the lighting of a rural church to demonstrate that these negative effects, while never eliminated, can at least be greatly reduced.
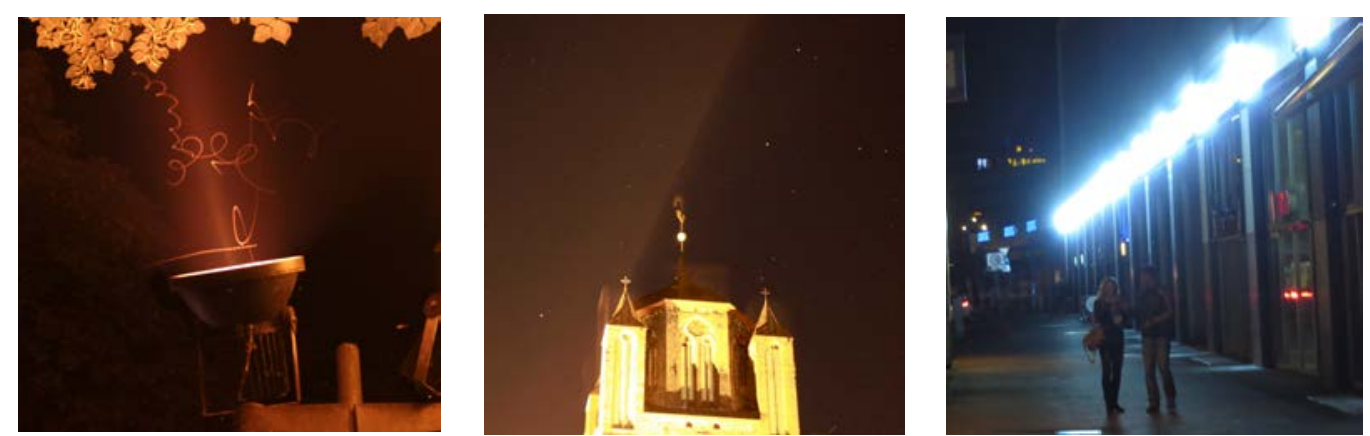

Figure 1: Insects attracted to architectural lighting (left), spill light illuminating the night sky (center), façade lighting on the exterior of the Alexanderplatz train station in Berlin. Photos by C Kyba, available under CC BY NC.

Light pollution is now widely recognized as a serious environmental problem. A great deal of recent work in biology has illuminated the unexpected impacts of light on animal physiology (e.g. [1-3]), including that of humans [4]. Light has dramatic effects on animal behavior [5-8], and is in many cases deadly [9-12]. Ecologists have demonstrated that light affects relationships between species, and are now building large experiments to measure the ecosystem-level effects [13]. Even seemingly passive plants such as urban trees are not immune from the impact of exposure to light at biologically incorrect times [14-15]. The light from cities spreads far beyond the city boundaries and returns to Earth as skyglow, with the result that $88 \%$ of the area of the European Union experiences significant levels of skyglow [16]. Furthermore, despite the introduction of LEDs, total global light emissions are continuing to grow [17].

In urban areas, outdoor area lighting such as street and parking lot lighting are the most important sources of light [18]. In rural areas of Europe, however, church facade lighting is often the brightest and most conspicuous source of lighting in a region. For example, Jechow et al. recently reported that $9 \%$ of the public light sources in a Spanish town of about 16,000 were for ornamental lighting, and that switching these lamps off reduced the artificial sky brightness overhead on a clear night by $20 \%$ at a location $1 \mathrm{~km}$ from the town center [19]. Church lighting is of particular concern for bats. Church belfries often provide a refuge for bats, and many bats will not roost in a floodlit church [20]. Recently, the lighting of the Church of the Three Kings (Cerkev sv. Trije Kralji, literally "Church of Saint Three Kings") in the municipality of Logatec, Slovenia, $\left(46.0103^{\circ} \mathrm{N}, 14.1687^{\circ} \mathrm{E}\right)$, was replaced. The dramatic improvement in reduction of energy, waste light, and visual appeal serve as a case study for reducing environmental impact from historic façade lighting.

The basic concept for the EcoSky lighting system used here developed within the "Life at Night" Life+ project, originally using metal halide lamps. The system has been used to reduce the light pollution from several hundred churches in Slovenia, as well as in other European countries. During the project, the attraction of moths to lit churches was studied [21], and it was found that the addition of masks greatly reduced the number of individuals and species attracted to the lit churches [22]. The Life at Night project also published recommendations for reducing the environmental impact of monument lighting [23].

\section{Prior lighting}

The previous church illumination system consisted of four $400 \mathrm{~W}$ reflectors: two metal-halide (color temperature $4000 \mathrm{~K}$, Fig. 2), and two high pressure sodium lamps (2200 K). These lit the church façade with an average luminance of $10.03 \mathrm{~cd} / \mathrm{m}^{2}$. A view of the church from one location is shown along with calculated luminance values (Fig. 3). Note that the average church façade luminance is calculated based on observations from both sides of the church, for this particular direction the average value was $7 \mathrm{~cd} / \mathrm{m}^{2}$. At this church approximately $80 \%$ of the light emitted by the lamps was not incident on the façade. This is unfortunately a fairly typical use fraction for churches illuminated by simple floodlights. The church is fairly isolated, in an area without other major lighting installations. The nearest other significant source of lights is about $2 \mathrm{~km}$ away in the village 
of Smrečje. In the past, the façade lighting was sometimes reduced due to a lamp burning out but not being immediately noticed, and there is no record of when lamps were replaced.

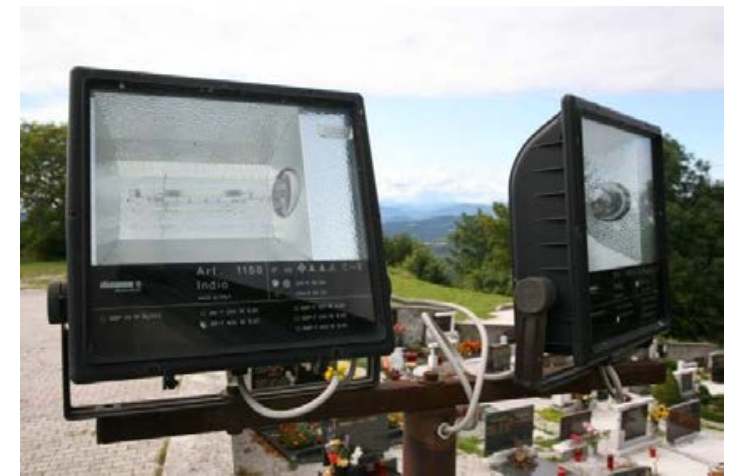

Figure 2: The two 400-Watt metal-halide reflector floodlamps used in the original lighting.

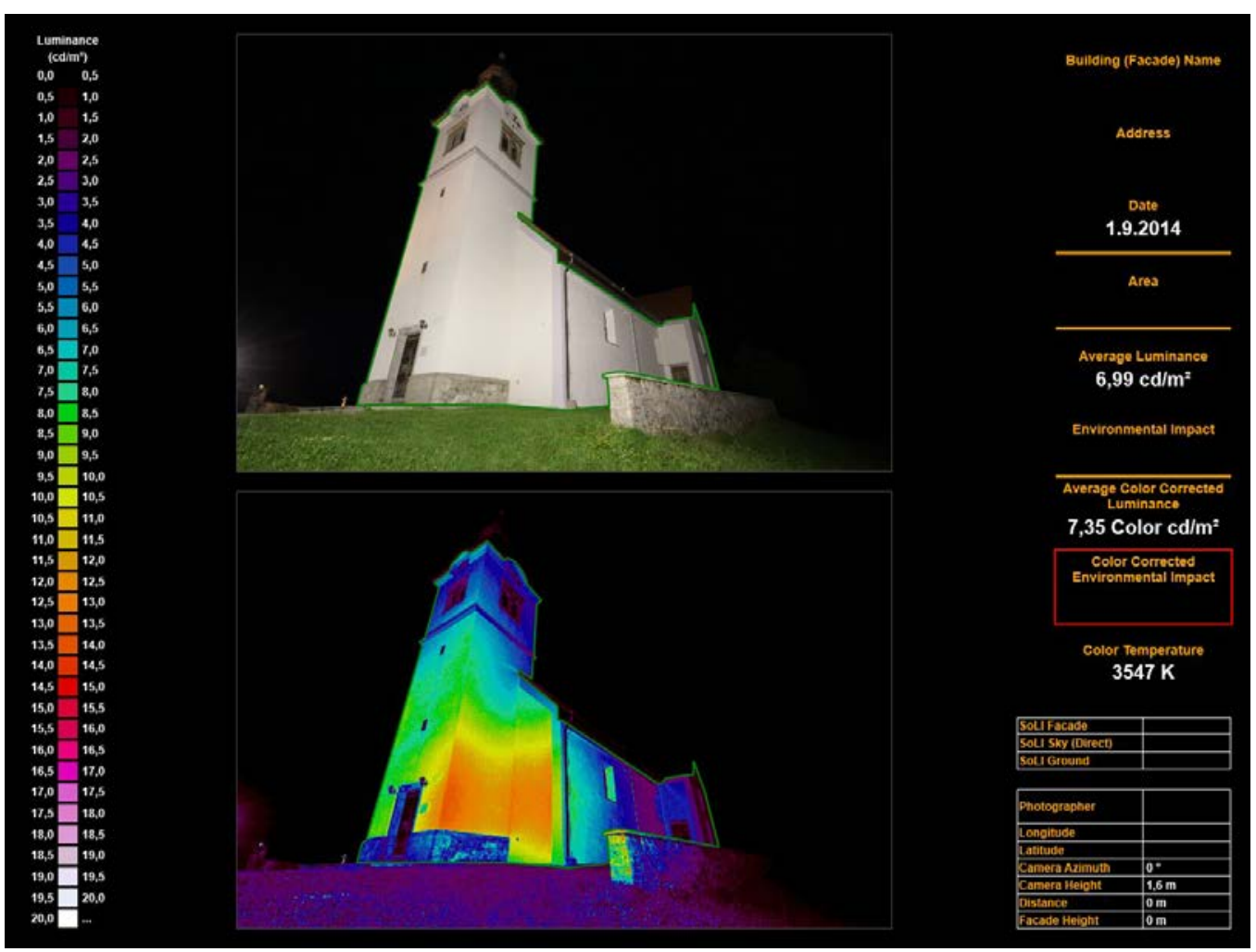

Figure 3: Photograph of the prior façade lighting from one vantage point (top). False color image showing calculated luminance for the given viewing location (bottom).

The isolation of the church makes it possible to directly identify the light coming from the church using data from the Visible Infrared Imaging Radiometer Suite Day-Night Band (VIIRS DNB) instrument on the Suomi NPP satellite [24]. The pixel size of a DNB observation is around $750 \mathrm{~m}$, so to uniquely identify a single lighting installation, it must be well separated from other lights. Furthermore, due to light scattering in the atmosphere, observations of installations in or near large cities can be affected by the glow of scattered light. This isolated church is therefore an ideal target for study with the DNB.

A web application called www.lightpollutionmap.info provides an easy way to examine the outcomes of lighting changes without the necessity of downloading and viewing the large satellite data files. The light pollution map application displays a custom made composite for each year, based on a selection of DNB data (the original data files on which the light pollution map app is based may be accessed from NOAO at www.ngdc.noaa.gov/eog 
/viirs/download_dnb_composites.html). These data are built up of observations on clear nights over the course of one or more months. For this analysis, we used an entire year's worth of data, in which periods with snow or heavy fog in Slovenia were excluded. This custom version of the data for Slovenia is available at www.lightpollutionmap.info/slovenia/. A $3 \mathrm{~km}^{2}$ area around the church was selected, and the total sum of the radiance was measured to be about $12 \mathrm{nW} / \mathrm{cm}^{2} \mathrm{sr}$ (Fig. 4). A relatively large region around the church was selected because although an object the size of a church fits entirely inside of a single DNB pixel, the process that creates the mosaic can spread the light among neighboring pixels, and light from the church can also reflect from nearby land.

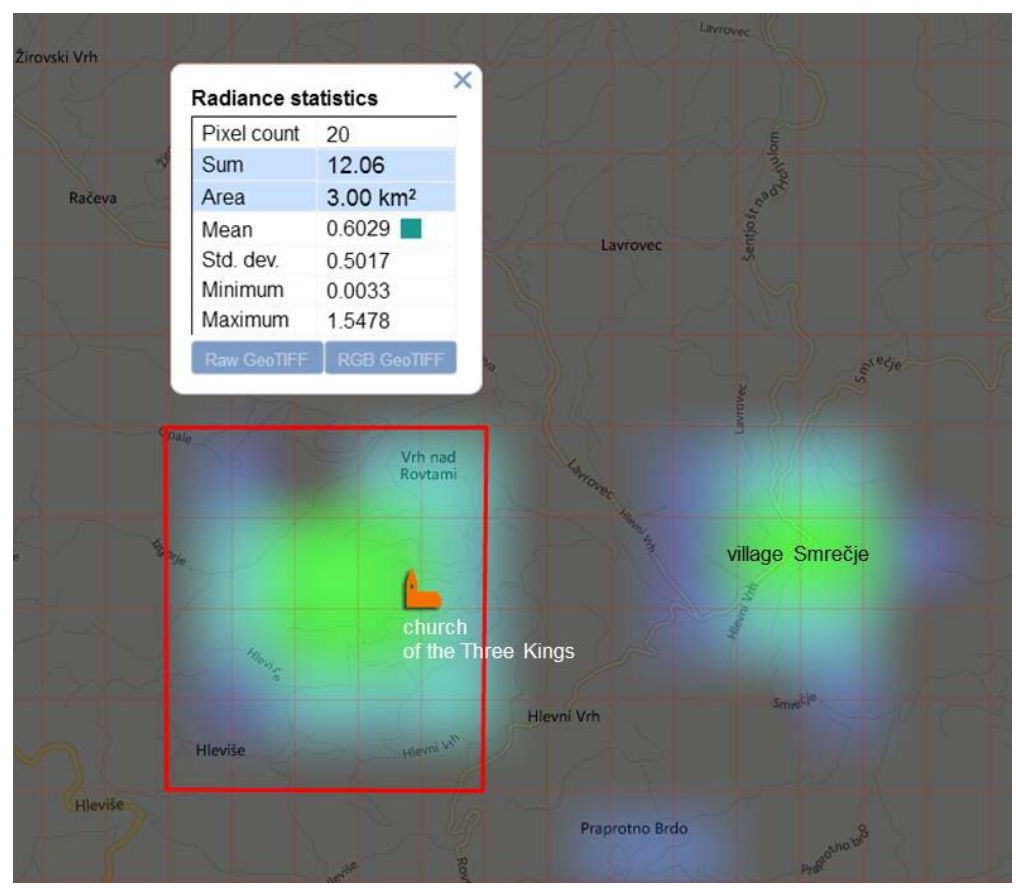

Figure 4: Screenshot from www.lightpollutionmap.info showing the upward emissions from the church of the Three Kings and the nearby village observed from space by the VIIRS Day-Night Band in 2013, before the lighting was replaced. The distance between lines on the displayed grid is about 320 meters horizontally and 460 meters vertically, so the total area shown is about $5 \mathrm{~km}$ by $4 \mathrm{~km}$.

\section{Replacement of the luminaires}

The new luminaires were mounted at an identical position to the previous ones, using the same masts. The church was photographed from the two locations where the luminaires would be installed, in order to prepare a mask for the area to be illuminated. This mask was mounted $17,8 \mathrm{~cm}$ away from a $29 \mathrm{~W}$ COB LED module with $19 \mathrm{~mm}$ diameter, and without a lens (Fig. 5). The LED had a color temperature of $2700 \mathrm{~K}$, and the façade was lit with an average luminance (weighted by area over multiple viewing directions) of $0.62 \mathrm{~cd} / \mathrm{m}^{2}$, a reduction of $94 \%$ in luminance. This new design is in compliance with the Slovenia "Decree of Limiting Values of Light Pollution", which requires that the average luminance value of the illuminated parts of facades cannot exceed $1 \mathrm{~cd} / \mathrm{m}^{2}$ and that a maximum of $10 \%$ of the light misses the façade. In unlit areas, even lower luminance values still stand out, and for another church façade project a value of only $0.05 \mathrm{~cd} / \mathrm{m}^{2}$ was used.

Power consumption compared to the original lighting was reduced by about $94 \%$. Note that as the power consumption for the original ballast is not known, the power for the ballast and LED driver are ignored here. Nevertheless, including these factors is not necessary in this case, as from a sustainability standpoint a 96\% and $94 \%$ reduction are effectively the same result. Spill light beyond the mask is controlled either by using a lens, or by mechanical blocking (as in this case), with the choice depending on the shape of the area to be lit its distance from the light source. The combined system of mask and light source is called an EcoSky LED. When the EcoSky LED is positioned at the exact location used to take the image to create the mask, it greatly limits spill light beyond 
the façade to be illuminated, with perhaps $3 \%$ of the light leaving the mask missing the church in this case. For optimal placement, it is essential that the alignment is verified during nighttime. The church was lit by a combination of two EcoSky LED lights (Fig. 6), for a total power consumption of $58 \mathrm{~W}$, a $96 \%$ reduction compared to the original lighting.

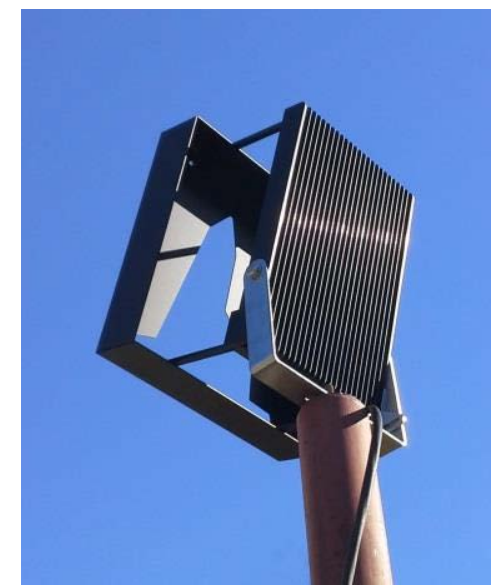

Figure 5: Photo of an EcoSky LED with mask for the Church of the Three Kings in place.

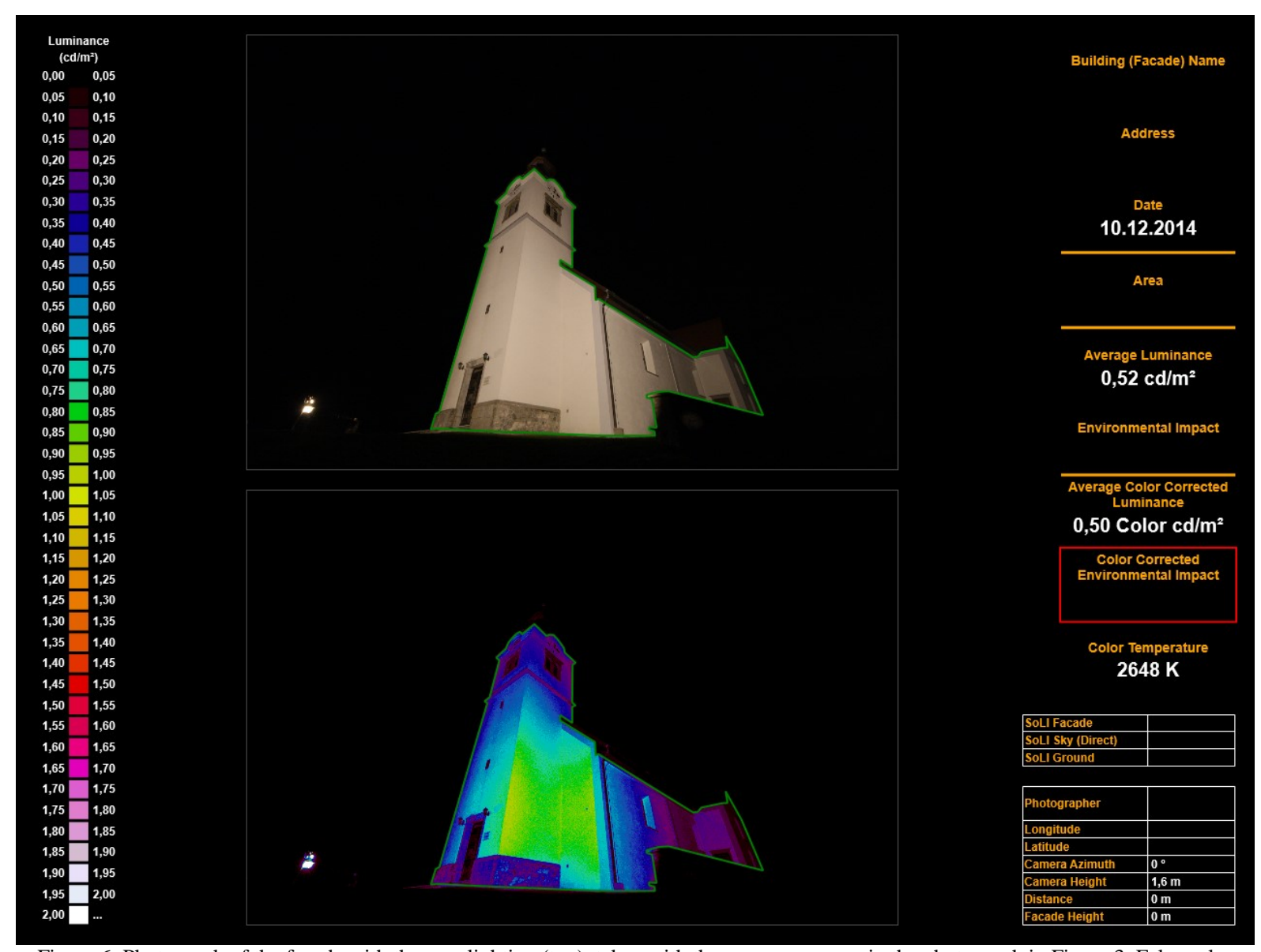

Figure 6: Photograph of the façade with the new lighting (top), taken with the same camera as in the photograph in Figure 3. False color image showing calculated luminance for the same viewing location as in Figure 3 (bottom). Note that the color scale for the false color image is reduced by 10 times compared to Figure 3 ! 
The photograph demonstrates that the façade continues to be very prominently lit against the intrinsically dark background. Despite this, the nighttime satellite observations from 2016 show that although the church illumination was on, the area is now lit near or below the detection threshold of the instrument (Fig. 7), and the summed light in the analysis area is greatly reduced (to $\sim 0.4$ summed $\mathrm{nW} / \mathrm{cm}^{2} \mathrm{sr}$ ) compared to before the lighting renovation. This sets a lower limit on the total reduction of waste light of a factor of about 30 . In this case, the satellite cannot be used to exactly measure the reduction in upward light, because the satellite data after the renovation consist mainly of noise. An exact measure would, however, be possible for larger lighting installations that remain bright enough for the sensor to clearly see above the noise threshold after the lighting revision (e.g. airports, prisons). A discussion of the potential of and challenges associated with using night lights data can be found in [25].

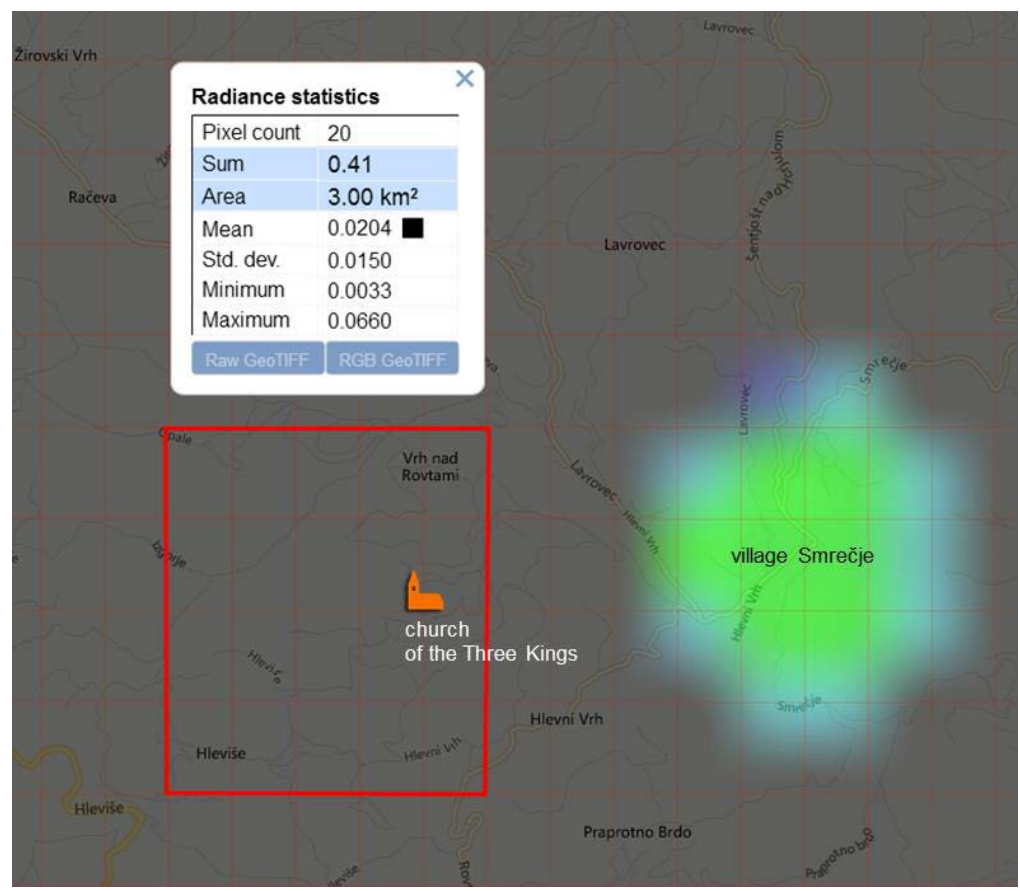

Figure 7: Screenshot from www.lightpollutionmap.info/slovenia showing the upward emissions from the Church of the Three Kings and the nearby village observed from space by the VIIRS Day-Night Band in 2016, after the lighting was replaced.

The reduction in artificial sky brightness caused by the church is even larger than the reduction in energy consumption, because of the reduction in spill light. A full environmental assessment of the reduction of skyglow would need to use a combination of ray-tracing and a skyglow model (see e.g. [26]). However, the importance of spill light can be demonstrated with a "back of the envelope calculation". This type of calculation is intended to clarify thinking about the problem, not to arrive at an exact answer. Consider the total output of the luminaires to be 1 . If the fraction of emitted light that illuminates the church is $\mathrm{C}$, the fraction spilled into the sky is $\mathrm{S}$, and the fraction absorbed by the mask is $\mathrm{M}$, then:

$$
\mathrm{C}+\mathrm{S}+\mathrm{M}=1
$$

The mask is assumed to be perfectly black, so none of the light shining on it escapes to the sky, whereas the fraction S directly shines into the sky. Of the light that hits the church, some fraction is absorbed, and the remainder reflects uniformly (Lambertian). Given the church's geometry, about half of the scattered light goes into the sky, while the other half heads towards the ground. Of that light, about $80-90 \%$ is absorbed, while the remainder reflects into the sky. If $a$ represents an attenuation factor that takes these processes into account, then the total fraction of the emitted light that escapes to the sky (U) is:

$$
\mathrm{U}=\mathrm{S}+\mathrm{Ca}
$$

For a fairly reflective white surface, a reasonable estimate of $a$ is 0.33 . Let us assume that the original illumination system had $\mathrm{S}=0.8$ and $\mathrm{C}=0.2$. The fraction of emitted light that ends up going into the sky was thus $\mathrm{U}_{\text {before }}=0.87$. For the replacement lighting system, assume $\mathrm{M}=0.77, \mathrm{~S}=0.03$, and $\mathrm{C}=0.2$. The fraction of light going into the sky is now $U_{\text {after }}=0.10$, a dramatic reduction. Note again that the goal here was not an exact calculation. Even a much 
more pessimistic assumption of $\mathrm{M}=0.74, \mathrm{~S}=0.06, \mathrm{C}=0.2$, $\mathrm{a}=0.4$ would yield $\mathrm{U}_{\mathrm{after}}=0.14$, which is still a dramatic reduction. On top of that, this reduction applies on top of the decrease in total lumen output of the lamps. Measuring the change in sky brightness caused by the church lighting is challenging, due to the relatively large contribution of (variable) natural light to the sky brightness in this area [27, 28], and the church's location at the top of a hill.

\section{Discussion and conclusion}

Defining exactly what "sustainable lighting" means is part of the raison d'être of this particular journal [29]. In our opinion, one important property of sustainable outdoor lighting is that it should meet, but not exceed, the minimum amount of light required for a given visual task. In heavily trafficked or high-crime pedestrian areas, for example, this would imply that faces can be recognized and obstacles seen at a distance of a few meters. Once this is possible, adding light serves no useful purpose, but only wastes energy (see e.g. [30, 31]). There is room for a philosophical discussion about whether decorative architectural lighting should ever be considered sustainable, as it is not strictly required (for example to ensure public safety).

Nevertheless, architectural lighting must surely be unsustainable if it is much brighter than the minimum necessary to highlight the lit object against the surroundings. In the case presented here, the original lights, and for that matter any design using more than $60 \mathrm{~W}$ of power, is clearly unsustainable. The original lighting of the church placed it into the photopic vision range, which is entirely inappropriate for an area without surrounding lighting. Such high luminance levels will spoil the dark adaptation of pedestrians in the area, making it difficult to see in the vicinity of the church. The final mesopic value of $0.62 \mathrm{~cd}$ was selected on the basis of experience in working with many parishes throughout Slovenia. However, it should be noted that given the isolated location of this church, it would still stand out even if a considerably lower luminance was chosen.

It would be interesting for a similar project in the future to attempt to observe the impact changes in lighting have on the sky through "differential photometry" (e.g. [19, 32]). This would require that the old lamps be left in place for comparison. Such a measurement would require an observation with only the original lamps, followed quickly by an observation with only the new lamps, and shortly thereafter an observation with all of the lamps off, in order to get the background component. The impact on the night sky would be highly dependent on the distance from the church, so to understand how different locations are affected either several cameras would need to be used, or else the procedure would need to be repeated multiple times. This, however, would be problematic with non-LED lighting, as it usually takes 10 or more minutes for gas discharge lamps to cool off, turn on, and regain full output.

The 96\% reduction in energy consumption and even larger reduction in contribution to artificial skyglow in this project demonstrate the remarkable degree to which light pollution can be reduced through proper design choices. The overly high power and poorly directed lighting of the original design are unfortunately in some sense not remarkable: many rural churches, castles, and other cultural sites in Europe are similarly carelessly lit. Improvements in lighting design could therefore stand to remarkably reduce the total energy consumption, cost, carbon emissions, and light pollution from cultural monument lighting in Europe. While this church was perhaps more brightly lit than average, the experience in installing the EcoSky LED at churches within Europe is that a reduction in waste light by a factor of at least 20 is usually achievable. Similar reductions have been verified on satellite images for other EcoSky LED installations, but because of the large pixel size of DNB images ( 750 m resolution), other lights are usually also present. Environmental monitoring of the light emission from individual objects would be made much more feasible if the satellite resolution was increased to 100 meters or better.

In closing, it is worth considering two final points. First, while artificial illuminated monuments may be aesthetically pleasing, as a matter of cultural heritage for monuments that predate electric lighting, a case can be made that adding lighting is nearly as inauthentic as painting the monument neon green would be. In rural areas especially, such lighting prevents experiencing the monuments as dark silhouettes against a bright starry sky, or appearing to glow on their own in reflected moonlight. Second, when monuments are located in rural areas, the ecological impact of the light pollution is greater than when they are located in cities. For these reasons, in many cases the sustainable choice of lighting for cultural heritage sites is no light at all. 


\section{Acknowledgements}

The authors acknowledge the funding received by the EU LIFE+ project LIFE09 NAT/SI/000378 "Life at Night” for the development of the EcoSky system. The authors also acknowledge the funding from the European Union's Horizon 2020 research and innovation programme under grant agreement No 689443 via project GEOEssential. This article is based upon work from COST Action ES1204 LoNNe (Loss of the Night Network), supported by COST (European Cooperation in Science and Technology). Image and Data processing by NOAA's National Geophysical Data Center.

\section{References}

[1] Robert, K. A., Lesku, J. A., Partecke, J., \& Chambers, B. (2015, October). Artificial light at night desynchronizes strictly seasonal reproduction in a wild mammal. In Proc. R. Soc. B (Vol. 282, No. 1816, p. 20151745). The Royal Society.

[2] Raap, T., Casasole, G., Pinxten, R., \& Eens, M. (2016). Early life exposure to artificial light at night affects the physiological condition: An experimental study on the ecophysiology of free-living nestling songbirds. Environmental Pollution, 218, 909-914.

[3] Brüning, A., Hölker, F., Franke, S., Kleiner, W., \& Kloas, W. (2018). Influence of light intensity and spectral composition of artificial light at night on melatonin rhythm and mRNA expression of gonadotropins in roach Rutilus rutilus. Fish Physiology and Biochemistry, 44(1), 1-12.

[4] Lunn, R. M., Blask, D. E., Coogan, A. N., Figueiro, M. G., Gorman, M. R., Hall, J. E., ... \& Stevens, R. G. (2017). Health consequences of electric lighting practices in the modern world: A report on the National Toxicology Program's workshop on shift work at night, artificial light at night, and circadian disruption. Science of The Total Environment, 607, 1073-1084.

[5] Perkin, E. K., Hölker, F., \& Tockner, K. (2014). The effects of artificial lighting on adult aquatic and terrestrial insects. Freshwater Biology, 59(2), 368-377.

[6] Firebaugh, A., \& Haynes, K. J. (2016). Experimental tests of light-pollution impacts on nocturnal insect courtship and dispersal. Oecologia, 182(4), 1203-1211.

[7] Ouyang, J. Q., Jong, M., Grunsven, R. H., Matson, K. D., Haussmann, M. F., Meerlo, P., ... \& Spoelstra, K. (2017). Restless roosts: Light pollution affects behavior, sleep, and physiology in a free- living songbird. Global Change Biology.

[8] Van Doren, B. M., Horton, K. G., Dokter, A. M., Klinck, H., Elbin, S. B., \& Farnsworth, A. (2017). Highintensity urban light installation dramatically alters nocturnal bird migration. Proceedings of the National Academy of Sciences, 201708574.

[9] Johnston, D. W., \& Haines, T. P. (1957). Analysis of mass bird mortality in October, 1954. The Auk, 74(4), 447-458.

[10] Salmon, M., Tolbert, M. G., Painter, D. P., Goff, M., \& Reiners, R. (1995). Behavior of loggerhead sea turtles on an urban beach. II. Hatchling orientation. Journal of Herpetology, 568-576.

[11] Eisenbeis, G. (2006). Artificial night lighting and insects: attraction of insects to streetlamps in a rural setting in Germany. Ecological consequences of artificial night lighting, 2, 191-198.

[12] Rodríguez, A., Holmes, N. D., Ryan, P. G., Wilson, K. J., Faulquier, L., Murillo, Y., ... \& Le Corre, M. (2017). Seabird mortality induced by land-based artificial lights. Conservation Biology, 31, 986-1001.

[13] Gaston, K. J., Visser, M. E., \& Hölker, F. (2015). The biological impacts of artificial light at night: the research challenge. 
[14] Somers-Yeates, R., Bennie, J., Economou, T., Hodgson, D., Spalding, A., \& McGregor, P. K. (2016, June). Light pollution is associated with earlier tree budburst across the United Kingdom. In Proc. R. Soc. B (Vol. 283, No. 1833, p. 20160813). The Royal Society.

[15] Knop, E., Zoller, L., Ryser, R., Gerpe, C., Hörler, M., \& Fontaine, C. (2017). Artificial light at night as a new threat to pollination. Nature, 548(7666), 206-209.

[16] Falchi, F., Cinzano, P., Duriscoe, D., Kyba, C. C., Elvidge, C. D., Baugh, K., ... \& Furgoni, R. (2016). The new world atlas of artificial night sky brightness. Science Advances, 2(6), e1600377.

[17] Kyba, C.C.M., Kuester, T., de Miguel, A.S., Baugh, K., Jechow, A., Hölker, F., Bennie, J., Elvidge, C.D., Gaston, K.J., Guanter, L. (2017). Artificially lit surface of Earth at night increasing in radiance and extent. Science Advances, 3(11), e1701528.

[18] Kuechly, H. U., Kyba, C. C., Ruhtz, T., Lindemann, C., Wolter, C., Fischer, J., \& Hölker, F. (2012). Aerial survey and spatial analysis of sources of light pollution in Berlin, Germany. Remote Sensing of Environment, 126, 39-50.

[19] Jechow, A., Ribas, S. J., Domingo, R. C., Hölker, F., Kolláth, Z., \& Kyba, C. C. (2018). Tracking the dynamics of skyglow with differential photometry using a digital camera with fisheye lens. Journal of Quantitative Spectroscopy and Radiative Transfer, 209, 212-223.

[20] Rydell, J., Eklöf, J., \& Sánchez-Navarro, S. (2017). Age of enlightenment: long-term effects of outdoor aesthetic lights on bats in churches. Royal Society Open Science, 4(8), 161077.

[21] Jež, M., Zakšek, V., Štanta, R., Zadravec, B, Verovnik, R. (2015) Favna nočnih metuljev (Lepidoptera) na izbranih osvetljenih cerkvah v Sloveniji. Natura Sloveniae, 17(2), 17-45.

[22] Verovnik, R., Fišer, Ž., \& Zakšek, V. (2015). How to reduce the impact of artificial lighting on moths: A case study on cultural heritage sites in Slovenia. Journal for Nature Conservation, 28, 105-111.

[23] Mohar A., Zagmajster, M., Verovnik, R., Skaberne, B.B., (2014). Nature-friendlier lighting of objects of cultural heritage (churches) - Recommendations. Life+ project brochure. URL:

http://ec.europa.eu/environment/life/project/Projects/index.cfm?fuseaction=home.showFile\&rep=file\&fil=Lifeat Night_Recommendations_EN.pdf (Access date 11 October 2017).

[24] Elvidge, C. D., Baugh, K., Zhizhin, M., Hsu, F. C., \& Ghosh, T. (2017). VIIRS night-time lights. International Journal of Remote Sensing, 38(21), 5860-5879.

[25] Kyba, C., Garz, S., Kuechly, H., de Miguel, A.S., Zamorano, J., Fischer, J., \& Hölker, F. (2015). Highresolution imagery of Earth at night: new sources, opportunities and challenges. Remote sensing, 7(1), 1-23.

[26] Aubé, M., \& Kocifaj, M. (2012). Using two light-pollution models to investigate artificial sky radiances at Canary Islands observatories. Monthly Notices of the Royal Astronomical Society, 422(1), 819-830.

[27] Bará, S., Espey, B., Falchi, F., Kyba, C. C. M., \& Nievas Rosillo, M. (2015). Report of the 2014 LoNNe intercomparison campaign. URL: http://eprints. ucm. es/32989/(Accessed 13 May 2016).

[28] Hänel, A., Posch, T., Ribas, S. J., Aubé, M., Duriscoe, D., Jechow, A., ... \& Spoelstra, H. (2018). Measuring night sky brightness: methods and challenges. Journal of Quantitative Spectroscopy and Radiative Transfer, 205, 278-290. 
[29] Kim, J.T., Beu, D (2015) Why an International Journal of Sustainable Lighting? Int J Sustain Light 34, p. 3-4.

[30] Narendran, N., Freyssinier, J. P., \& Zhu, Y. (2016). Energy and user acceptability benefits of improved illuminance uniformity in parking lot illumination. Lighting Research \& Technology, 48(7), 789-809.

[31] Fotios, S., Cheal, C., Fox, S., \& Uttley, J. (2017). The transition between lit and unlit sections of road and detection of driving hazards after dark. Lighting Research \& Technology, 1477153517725775.

[32] Mohar A., (2011 October). Importance of nearby lighting on light pollution. Talk at the $11^{\text {th }}$ European Symposium for the Protection of the Night Sky. Osnabrück, Germany. URL:

http://www.lichtverschmutzung.de/symposium_2011/zubehoer/download.php?sub=friday_aftern_sess1\&file=05 _Mohar.pdf 